\title{
Upaya Meningkatkan Hasil Belajar Tenis Meja melalui Media Dinding
}

\author{
Jhony Hendra ${ }^{\otimes 1}$, Yustinar ${ }^{2}$ \\ (1) Pendidikan Jasmani Kesehatan dan Rekreasi, STKIP Muhammadiyah Muara Bungo \\ (2) Sekolah Dasar Negeri 50/II Lubuk Landai
}

$\square$ Corresponding author

[jhony.jho.hendra@gmail.com]

\begin{abstract}
Abstrak
Penelitian ini dilatarbelakangi masih banyak siswa yang belum mampu melakukan teknik dasar bermain tenis meja, selain itu banyak dari siswa yang belum tuntas mencapai Kriteria Ketuntasan Minimum (KKM) dengan nilai 70. Penerapan pembelajaran dengan media dinding dapat meningkatkan hasil pembelajaran tenis meja. Tujuan dari penelitian ini adalah untuk mengetahui: peningkatan hasil belajar tenis meja melalui penerapan modifikasi alat pembelajaran. Jenis penelitian ini adalah penelitian tindakan kelas yang dilaksanakan dalam dua siklus. Setiap siklus mempunyai 4 langkah yaitu: perencanaan, pelaksanaan, observasi, dan refleksi. Sumber data penelitian ini adalah siswa kelas V SD yang berjumlah 31 orang yang terdiri dari 16 siswa laki-laki dan 12 siswa perempuan. Teknik pengumpulan data dengan observasi, tes kemampuan dan hasil belajar bermain tenis meja. Teknik analisis data yang digunakan dalam penelitian ini adalah secara statistic deskriptif kualitatif. Berdasarkan hasil penelitian bahwa pembelajaran melalui penerapan modifikasi alat pembelajaran dapat meningkatkan hasil belajar tenis meja. Dari hasil analisis yang diperoleh terjadi peningkatan yang sangat signifikan dari siklus I dan siklus II. Hasil belajar pada siklus I dalam kategori tuntas adalah $41,94 \%$ dan pada siklus II terjadi peningkatan hasil belajar siswa dalam kategori tuntas sebesar $87,10 \%$.
\end{abstract}

Kata Kunci: hasil belajar; tenis meja; media dinding

\section{Abstract}

The background of this research is that there are still many students who have not been able to do the basic techniques of playing table tennis. In addition, many students have not yet completed the Minimum Completion Criteria (KKM) with a value of 70 . The application of learning using wall media can improve the results of table tennis learning. The purpose of this study was to determine: improvement of table tennis learning outcomes through the application of modified learning tools. This type of research is a classroom action research conducted in two cycles. Each cycle has 4 steps, namely: planning, implementing, observing, and reflecting. The data source of this study were 31 students of grade V SD, consisting of 16 male students and 12 female students. Data collection techniques by observation, ability tests and learning outcomes to play table tennis. The data analysis technique used in this research is qualitative descriptive statistics. Based on the research results, learning through the application of modified learning tools can improve learning outcomes for table tennis. From the results of the analysis obtained a very significant increase from cycle I and cycle II. The learning outcomes in the first cycle in the complete category were $41.94 \%$ and in the second cycle there was an increase in student learning outcomes in the complete category by $87.10 \%$.

Keyword: learning outcomes; table tennis; wall media.

\section{PENDAHULUAN}

Pendidikan berperan penting dalam mencerdaskan kehidupan bangsa demi peningkatan kualitas sumber daya manusia yang bermutu guna menghasilkan manusia yang berkualitas sesuai dengan fungsi dan tujuan pendidikan nasional. Tujuan pendidikan nasional adalah tujuan pendidikan yang ingin dicapai secara nasional yang dilandasi oleh falsafat suatu negara (Hernawan, 2007:119). Undang- undang RI Nomor 3 Pasal 1 Tahun 2005 menyatakan bahwa Olahraga Pendidikan adalah jasmani dan olahraga yang dilaksanakan sebagai bagian proses pendidikan yang teratur dan berkelanjutan untuk memperoleh pengetahuan, kepribadian, keterampilan, kesehatan dan kebugaran jasmani (Redaksi Sinar Grafika, 2003). Pendidikan jasmani, olahraga dan kesehatan merupakan program pengajaran yang sangat penting dalam pembentukan kebugaran para siswa. Pembelajaran jasmani olahraga dan kesehatan ini diharapkan dapat mengarahkan siswa untuk dapat beraktivitas olahraga agar tercipta generasi muda yang sehat dan kuat. Pendidikan jasmani olahraga dan kesehatan yang diajarkan di sekolah- sekolah memiliki peranan yang sangat penting dalam berbagai hal diantaranya: memberikan kesempatan kepada siswa untuk terlibat langsung dalam berbagai 
pengalaman belajar melalui aktifitas jasmani, permainan, dan cabang olahraga terpilih yang dilakukan secara sistematis. Pembekalan pengalaman belajar yang diarahkan untuk membina fisik, perkembangan watak, keterampilan gerak, kepribadian yang harmonis dan sekaligus membentuk pola hidup sehat dan bugar sepanjang hayat.

Pendidikan Jasmani Olahraga dan Kesehatan memiliki peranan yang sangat penting dalam mengintensifkan penyelenggaraan pendidikan sebagai suatu proses pembinaan manusia yang berlangsung seumur hidup. Melalui pendidikan jasmani siswa diharapkan dapat memperoleh berbagai pengalaman untuk mengungkapkan kesan pribadi yang menyenangkan, kreatif, inovatif, terampil, meningkatkan dan memelihara kebugaran jasmani serta pemahaman terhadap gerak manusia. Pendidikan jasmani adalah suatu proses pembelajaran melalui aktifitas jasmani, yang didesain secara sistematik untuk meningkatkan pertumbuhan dan perkembangan, meningkatkan kemanpuan dan keterampilan jasmani, kecerdasan dan perkembangan watak, serta nilai dan sikap yang positif (Syarifuddin dan Muhadi, 1992:4)

Ruang lingkup pembelajaran jasmani yang diajarkan di SD ditekankan pada usaha memacu pertumbuhan dan perkembangan jasmani mental, emesional, dan sosial. Jenis-jenis kegiatan yang diajarkan di SD secara garis besar meliputi dua kegiatan yakni kegiatan pokok dan kegiatan pilihan. Salah satu dari enam jenis kegiatan pilihan yaitu permainan tenis meja (Syarifuddin dan Muhadi, 1992:5)

Aktivitas jasmani dalam pengertian ini dipaparkan sebagai kegiatan pelaku gerak untuk meningkatkan keterampilan motorik dan nilai-nilai fungsional yang mencakup aspek kognitif, afektif, dan sosial. Bebarapa kegiatan pilihan dalam ruang lingkup pendidikan jasmani melalui permainan dan olahraga, salah satu diantaranya adalah tenis meja yang merupakan salah satu contoh olahraga menggunakan net (net game) yang dapat dilakukan di luar dan di dalam kelas yang tidak membutuhkan tempat yang luas. Dalam kurikulum tingkat satuan pendidikan salah satunya menyebutkan bahwa strategi pembelajaran adalah melaksanakan Pembelajaran Aktif, Inovatif, Kreatif, Efektif, dan Menyenangkan (PAIKEM). Strategi pembelajaran PAIKEM merupakan salah satu strategi yang dapat diterapkan dalam pembelajaran, karena bidang garapannya tertuju bagaimana cara: (1) pengorganisasian materi pembelajaran, (2) menyampaikan atau menggunakan metode pembelajaran, dan (3) mengelola pembelajaran (Hamzah dan Mohamad, 2016:60). Untuk mencapai tiga garapan tersebut di atas, seorang guru bisa memodifikasi alat pembelajaran dan dapat dikaitkan dengan kondisi lingkungan pembelajaran.

Guru dapat mengurangi atau menambah kompleksitas dan kesulitan tugas ajar dengan cara memodifikasi peralatan yang digunakan untuk melakukan skill itu, misalkan berat- ringannya, tinggirendahnya, panjang- pendeknya peralatan yang digunakan.

Salah satu olahraga permainan yang masuk dalam materi Kompetensi Dasar mata pelajaran pendidikan jasmani adalah tenis meja. Di dalam permainan tenis meja ada beberapa teknik yang perlu dipelajari yaitu cara memegang bet, memukul, dan cara berdiri. Tidak dapat dipungkiri bahwa dalam proses belajar-mengajar yang bersifat klasikal (hanya menyampaikan teori tanpa langsung dipraktikkan) akan menghadapi permasalahan yang heterogen terhadap kemampuan siswa. Dimana kurangnya kreatifitas seorang guru pendidikan jasmani di dalam mengemas materi pembelajaran pendidikan jasmani dianggap sebagai penyebabnya, sehingga banyak dari siswa yang tidak tuntas nilai Kriteria Ketuntasan Minimal (KKM) dengan nilai 70. Untuk itu dituntut seorang guru pendidikan jasmani yang mampu menguasai berbagai model atau pendekatan pembelajaran praktik, sehingga pembelajaran dapat berlangsung dengan baik dan berkualitas.

Hasil dari pengamatan proses pembelajaran tenis meja pada siswa kelas V SD Negeri 50/II Lubuk Landai Kecamatan Tanah Sepenggal Lintas Kabupaten Bungo belum berjalan dengan baik, masih banyak siswa yang belum bisa melakukan teknik dasar permainan tenis meja, dalam proses pembelajaran bermain tenis meja banyak siswa yang belum mempraktikkan teori-teori yang dipergunakan dalam permaianan tenis meja. Dalam proses pembelajaran permainan tenis meja, yang dilakukan guru sebagai penulis selama lima tahun banyak siswa yang belum menguasai teknik dasar permainan tenis meja. Alasan yang mendasar faktor tersebut di atas yaitu dari jumlah siswa secara keseluruhan 297 orang, hanya memiliki satu buah lapangan tenis meja. Dari jumlah siswa tersebut di atas, seharusnya skolah memiliki sekurang-kurangnya lima buah lapangan tenis meja dan bet 20 buah. sedangkan pembelajaran tenis meja yang dilakukan selama ini yaitu pembelajaran tanpa modifikasi alat pembelajaran, yaitu dengan menggunakan alat yang sebenarnya sangat terbatas dan tidak seimbang dengan jumlah siswa.

\section{METODE PENELITIAN}

Jenis penelitian ini adalah Penelitian Tindakan Kelas (PTK). Penelitian ini merupakan penelitian tindakan kelas (classroom action research) menurut Arikunto, dkk (2014:3) penelitian tindakan kelas merupakan suatu pencermatan terhadap kegiatan belajar berupa sebuah tindakan, yang segaja dimunculkan dan terjadi dalam sebuah kelas secara bersama. Menurut Ekawarna, (2010:4) penelitian tindakan kelas adalah Penelitian tindakan (action reseach) yang dilksnakan oleh guru di dalam kelas. Dalam penelitian ini guru diberdayakan dari sudut pengembangan profesionalitas sedangkan siswa mendapat manfaat dari upaya guru 
karena mendapat layanan yang lebih baik karena dampak dari meningkatnya kualitas pembelajarannya. Muslich, Mansur (2014:41) Penelitian Tindakan Kelas adalah penelitian yang dilakukan oleh guru di dalam kelasnya sendiri melalui refleksi diri, dengan tujuan untyuk memperbaiki kinerjanya sebagai guru, sehingga proses pendidikan itu dpat berjalan dengan baik, dan hasil belajar siswa meningkat.

Penelitian Tidakan Kelas ini merupakan penelitian yang mengacu kepada tidakan yang dapat dilakukan secara langsung dalam usaha memperbaiki proses pembelajaran. Penelitian ini dipilih karena memiliki karakteristik yang sesuai dengan tujuan penelitian, yakni untuk menigkatkan hasil belajar penjas terutama mengusai teknik dasar permainan tenis meja.

Penelitian ini dilaksanakan di SD Negeri 50/II Lubuk Landai Kecamatan Tanah Sepenggal Lintas Kabupaten Bungo. Waktu penelitian siklus I sesuai dengan jadwal pelajaran penjas kelas V. Setelah berdiskusi dengan kolaborator terhadap kelemahan dan kekurangan siklus I, dilanjutkan pebaikan pada siklus II. Subjek penelitian ini adalah siswa kelas V SD Negeri 50/II Lubuk Landai Kecamatan Tanah Sepenggal Lintas Kabupaten Bungo yang berjumlah 31 siswa terdiri dari 16 siswa laki-laki dan 15 siswa perempuan.

Metode penelitian yang digunakan adalah Penelitian Tindakan Kelas (PTK). Menurut Arikunto (2014:75) menyatakan bahwa "penelitian tindakan yang diawali dengan perencanaan (planning), penerapan tindakan (action), mengobservasi dan mengevaluasi tindakan (observation and evaluation), dan melakukan refleksi (reflecting), dan seterusnya sampai perbaikan atau peningkatan yang diharapkan tercapai (criteria keberhasilan). Adapun tahapan siklus pada Penelitian Tindakan Kelas ini dapat diterangkan melalui gambar sebagai berikut:

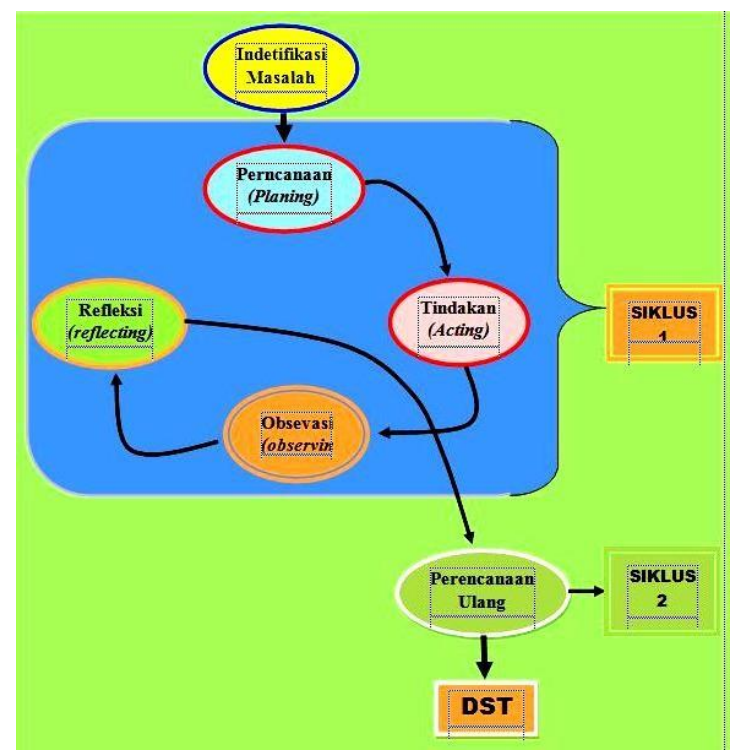

Gambar 1. Alur Tahapan Siklus Penelitian Tidakan Kelas Sumber: Ekawarna, (2010:16)

Langkah-langkah penelitian secara prosedurnya dilaksanakan secara partisipatif atau kolaboratif antara (guru dengan tim lainya) bekerjasama, mulai dari tahap orientasi hingga penyusunan rencana tindakan dalam siklus pertama, diskusi yang bersifat analitik, kemudian dilanjutkan dengan refleksi-evaluatif atas kegiatan yang dilakukan pada siklus pertama, untuk kemudian mempersiapkan rencana modifikasi, koreksi, atau pembetulan, dan penyempurnaan pada siklus berikutnya.

Adapun teknik pengumpulan data penelitian ini di antaranya melalui tes praktek, observasi lapangan, dan dokumentasi. Untuk mengumpulkan data, langkah pertama yang dilakukan yaitu menyusun rumusan pengertian secara singkat yang ditemukan dalam pembelajaran setelah itu penyusunan sajian data yang ditulis dan agar lebih jelas dapat dilengkapi dengan gambar, tabel, photo.

Melalui pembelajaran teknik dasar permainan tenis meja dengan penggunaan modifikasi alat bantu pembelajaran diharapkan penguasaan teknik dasar permainan tenis meja siswa meningkat menjadi lebih baik dibandingkan sebelumnya. Kemampuan yang diharapkan adalah siswa dapat menguasai cara bermain tenis meja dengan benar dan baik. Dalam penelitian ini ditentukan indikator keberhasilan yaitu apabila pada siklus pertama mencapai 50\% dan pada siklus ke dua mencapai $80 \%$ dari jumlah siswa (21 siswa) dapat memperoleh nilai penguasaan teknik bermain tenis meja atas sama atau lebih dari Kriteria Ketuntasan Minimal (KKM) yaitu nilai 70.

PTK ini bertujuan untuk mengukur sejauh mana aktivitas guru dan siswa dalam mengusai teknik dasar tenis meja dengan pembelajaran yang inovatif, dan mengukur tingkat kepuasan siswa dalam mengikuti proses belajar-mengajar tenis meja dengan pembelajaran inovatif. Untuk melihat sejauh mana aktivitas guru dan 
siswa dalam proses belajar-mengajar dan tingkat kepuasan belajar siswa dari proses pembelajaran dapat dilihat dari pencapaian hasil pembelajaran yang sudah ditentukan pada tabel di bawah ini.

Teknik analisis data. Data yang dikumpulkan pada setiap kegiatan observasi dari pelaksanakan siklus PTK dianalisis secara deskriptif dengan menggunakan teknik persentase untuk melihat kecenderungan yang terjadi dalam kegiatan pembelajaran. Sumber data. Data yang dikumpulkan dalam penelitian ini meliputi informasi tentang keadaan siswa dilihat dari aspek kuantitatif dan kualitatif. Aspek kuantitatif yakni hasil pengukuran kemampuan penguasaaan bermain tenis meja. Sedangkan aspek kualitatif didasarkan atas hasil pengamatan dan catatan pembelajaran selama penelitian berlangsung.

Instrumen yang digunakan dalam penelitian ini adalah praktek melakukan gerakan teknik dasar bermain tenis meja, yaitu tes untuk mengukur kemampuan bermain tenis meja. Instrumen tes yang digunakan dalam penelitian ini adalah tes bermain tenis meja yang bertujuan untuk mengukur keterampilan siswa dalam menguasai teknik dasar permainan tenis meja.

\section{HASIL DAN PEMBAHASAN \\ Deskripsi Kondisi Awal (Pra Siklus)}

Sebelum melaksanakan poses penelitian tindakan kelas, terlebih dahulu peneliti melakukan kegiatan survey awal untuk mengetahui keadaan nyata yang ada di lapangan. Hasil kegiatan survey awal tersebut adalah a) Siswa kelas V SD Negeri 50/II Lubuk Landai Kecamatan Tanah Sepenggal Lintas Kabupaten Bungo, yang mengikuti materi pelajaran penjas khususnya permainan tenis meja adalah 31 siswa, yang terdiri atas 16 siswa laki-laki dan 15 siswa perempuan. Dilihat dari proses pembelajaran tenis meja khususnya cara bermaian tenis meja, dapat dikatakan proses pembelajaran dalam kategori kurang berhasil. b) Siswa kurang memiliki perhatian dan motivasi dalam pembelajaran bermain tenis meja, sebab guru kurang kreatif dalam mengajar permainan tenis meja. c) Dari hasil pengamatan yang dilakukan diperoleh informasi bahwa siswa cenderung sulit diatur saat materi bermain tenis meja berlangsung. Saat mengikuti materi, siswa menunjukkan sikap seenaknya sendiri, tidak memperhatikan penjelasan guru, tidak memperhatikan pelajaran dengan sepenuhnya, ada yang berbicara dengan teman, bahkan ada yang bermain sendiri dengan temannya. d) Kesulitan menemukan contoh model pembelajaran bermain tenis meja yang baik dan benar. Seringkali contoh yang disampaikan melalui peragaan langsung, kurang dapat dicermati oleh siswa secara baik, sebab siswa kurang dapat melihat kondisi gerakan teknik bermain tenis meja yang diperagakan oleh guru, baik karena kurangnya antusiasme siswa atau contoh gerakan kurang dapat dipahami oleh siswa. e) Kurang bisa dapat menarik perhatian siswa dalam pembelajaran. Kurang kreatif untuk membuat cara agar siswa tertarik dan senang mengikuti materi bermain tenis meja. f) Sedikit kesulitan menemukan pendekatan pembelajaran yang baik kepada siswa. pembelajaran yang monoton atau konvensional mengakibatkan motivasi belajar siswa menurun, sehingga akan berdampak pada rendahnya kemampuan siswa dalam bermain tenis meja.

Sebelum melakukan pelaksanaan tindakan maka peneliti dan kolaborator melakukan pengambilan data awal penelitian. Ini dimaksudkan untuk mengetahui kondisi awal keadaan kelas pada materi permainan tenis meja. Adapun diskripsi data yang diambil adalah hasil belajar permainan tenis meja. Kondisi awal hasil belajar bermain tenis meja sebelum diberikan tindakan model pembelajaran melalui penerapan modifikasi alat pembelajaran berdasarkan tabel nilai pada Bab I, disajikan dalam bentuk tabel 1 .

Tabel 1. Diskripsi Data Awal Hasil Belajar Bermain Tenis Meja

\begin{tabular}{|c|c|c|c|c|}
\hline Rentang Nilai & Keterangan & Kreteria & Jumlah anak & $\%$ \\
\hline$\geq 90$ & Memuaskan & Tuntas & 0 & 0 \\
\hline $80-89$ & Baik & Tuntas & 0 & 0 \\
\hline $70-79$ & Cukup & Tuntas & 9 & 29,03 \\
\hline $61-69$ & Kurang & Tidak Tuntas & 5 & 16,13 \\
\hline$\leq 60$ & Gagal & Tidak Tuntas & 17 & 54,84 \\
\hline \multicolumn{3}{|c|}{ Jumlah } & 31 & 100 \\
\hline
\end{tabular}

Berdasarkan hasil diskripsi rekapitulasi data awal sebelum diberikan tindakan maka dapat dijelaskan bahwa mayoritas siswa belum menunjukan hasil belajar yang baik, dengan prosentase ketuntasan belajar $29,03 \%$ siswa.

Melalui diskripsi data awal yang telah diperoleh tesebut masing-masing aspek menunjukkan kriteria keberhasilan pembelajaran yang kurang. Maka disusun sebuah tindakan untuk meningkatkan kualitas pembelajaran materi bermain tenis meja pada siswa kelas V SD Negeri 50/II Lubuk Landai Kecamatan Tanah Sepenggal Lintas Kabupaten Bungo, melalui penerapan modifikasi alat pembelajaran. Pelaksanaan tindakan akan dilakukan sebanyak 2 siklus, yang masing masing siklus terdiri atas 4 tahapan, yakni: (1) Perencanaan, (2) Pelaksanaan Tindakan, (3) Observasi dan interprestasi, (4) Analisis dan Refleksi. 


\section{Siklus I}

Perencanaan tindakan pada siklus I pada tanggal 13 Mei 2017, sebagai berikut: 1) Peneiti melakukan analisis kurikulum untuk mengetahui kompetensi dasar yang akan disampaikan kepada siswa dalam pembelajaran Pendidikan Jasmano Olahraga dan Kesehatan. 2) Membuat rencana pembelajaran dengan mengacu pada tindakan (treatment) yang diterapkan dalam PTK, yaitu penerapan modifikasi alat pembelajaran untuk permainan tenis meja. 3) Menyiapkan media yang diperlukan untuk membantu pengajaran. 4) Menyusun lembar pengamatan pembelajaran.

Tahap pelaksanaan dilakukan dengan melaksanakan scenario pembelajaran yang telah direncanakan, sebagai berikut: 1) Pemanasan; menjelaskan kegiatan belajar mengajar secara umum dan melakukan pemanasan. Pemanasan dikemas dalam sebuah permainan sederhana yaitu Hitam dan Hijau. Caranya siswa dibagi menjadi dua kelompok tim hitam dan tim hijau, di buat satu bans setiap tim dan di hadapkan saling membelakangi, guru sebagai pengatur permainan, bila guru bilang hitam, tim hijau mengejar tim hitam dengan melompat dan tim hitam melompat ke depan lurus agar tidak tertangkap, bila tim hitam sampai batas belum tertangkap maka tim hijau menggendong tim hitam dari batas menuju ke posisi awal tetapi apabila tim hitam tertangkap maka tim hitam yang menggendong, apabila guru bilang hijau maka tim hitam yang mengejar.

Selanjutnya 2) Inti Pelajaran; memberi panjelasan materi yang akan diberikan, siswa melakukan gerak dan teknik dasar gerakan servis pada permainan tenis meja, siswa di bagi menjadi 2 regu. Siswa melakukan gerakan servis ke arah siswa regu yang lain dan kembali ke barisan dan menempati tempat yang paling belakang, siswa melakukan gerakan menerima servis supaya bola kembali ke area permainan lawan, siswa melakukan latihan bermain tenis meja dengan cara memantulkan bola ke arah dinding, dan siswa mencoba melakukan rangkaian gerakan permainan tenis meja dengan menggunakan media dinding sebagai lawan. Setelah melakukan teknik-teknik bermain tenis meja melalui penerapan modifikasi alat pembelajaran, kemudian siswa melakukan rangkaian gerakan secara keseluruhan dengan lapangan yang sesungguhnya dan sebagai lawannya adalah teman sendiri. Siswa melakukan sesuai urutan absen.

Pada kegiatan penutup dilakukan; penenangan/pendinginan, siswa duduk bersap, rapat, dan saling memijat, laki-laki dan perempuan di pisah, evaluasi mengenai pembelajaran yang telah dilakukan, dan berdoa kemudian dibubarkan.

Pada dasarnya pembelajaran melalui pendekatan modifikasi alat pembelajaran cukup memberikan gairah dan semangat baru pada pembelajaran Tenis Meja, hal ini dapat diamati dari sikap siswa yang tak kenal menyerah pada saat melakukan tes dan selalu ingin mengulangi permainan ketika hasilnya belum memenuhi target yang diharapkan. Masih ada kesempatan pada siklus II dengan harapan hasilnya akan lebih baik.

Tabel 2. Diskripsi Data Akhir Siklus I Hasil Belajar bermain tenis meja

\begin{tabular}{|c|c|c|c|c|}
\hline Rentang Nilai & Keterangan & Kreteria & $\begin{array}{c}\text { Jumlah } \\
\text { anak }\end{array}$ & $\%$ \\
\hline$\geq 90$ & Memuaskan & Tuntas & 0 & 0 \\
\hline $80-89$ & Baik & Tuntas & 0 & 0 \\
\hline $70-79$ & Cukup & Tuntas & 13 & 41,94 \\
\hline $61-69$ & Kurang & Tidak Tuntas & 13 & 41,94 \\
\hline$\leq 60$ & Gagal & Tidak Tuntas & 5 & 12,90 \\
\hline \multicolumn{3}{|c|}{ Jumlah } & 31 & 100 \\
\hline
\end{tabular}

Dari tabel 2 menujukkan bahwa hasil belajar siswa meningkat sesuai target capaian yang dicantumkan pada proposal. Meskipun demikian, masih perlu peningkatan pada metode yang diterapkan. Adapun keberhasilan dan kegagalan yang terjadi pada pertemuan kali ini adalah sebagai berikut:

\section{Keberhasilan guru/siswa:}

Berdasarkan pada kondisi awal, siswa menunjukkan hasil belajar yang cukup bagus dengan prosentase siswa yang tuntas $41,94 \%$ dan siswa yang belum tuntas $58,06 \%$.

\section{Kendala yang dihadapi guru/siswa:}

Kendala demi kendala bisa diatasi sedikit demi sedikit meskipun masih perlu peningkatan dan pengembangan. Kendala tersebut diantaranya adalah masih banyaknya siswa yang bermain sendiri dan tidak aktif dikarenakan terlalu panjangnya antrian serta kurangnya alat berupa bet. Demi tercapainya hasil yang maksimal pendekatan internal pada setiap individu siswa masih sangat berperan terhadap semangat siswa. Observasi aktivitas guru dalam proses penelitian siklus I adalah sebagai berikut; dalam membuka pelajaran sudah baik, keterampilan menjelaskan materi pada siswa baik, pengelolaan kelas cukup baik walaupun masih ada sedikit kegaduhan, melaksanakan pembelajaran sesuai dengan RPP, interaksi dengan siswa dan member motivasi terhadap siswa, mengarahkan dan membimbing siswa agar lebih baik, menutup pelajaran 


\section{Rencana Perbaikan}

Berdasarkan hasil analisis dalam pembelajaran siklus satu, maka perlu ada perbaikan-perbaikan pada siklus berikutnya, antara lain adalah: a) mempersiapkan siswa secara fisik dengan mengbimbau siswa supaya tidak melakukan gerakan yang menguras tenaga sebelum latihan, misalnya bermain kejar- kejaran dengan temannya dan bercanda sendiri, b) melakukan pendekatan internal lebih intensif pada siswa yang dirasa masih kurang berhasil, c) memberikan motivasi lebih kepada siswa supaya menjadi tambah semangat dalam mengikuti kegiatan belajar mengajar yang dilakukan dalam pembelajaran tenis meja, dan d) menambahkan bet agar antrian tidak terlalu panjang sehingga siswa tidak banyak yang menganggur

\section{Siklus II}

Berdasarkan dari hasil analisis dan refleksi pada siklus pertama, maka perencanaan tindakan pada siklus II tanggal 20 Mei 2017 adalah sebagai berikut: 1) membuat RPP dengan mengacu pada pertemuan sebelumnya. Pembelajaran dengan modifikasi alat pembelajaran yang pada pertemuan sebelumnya kurang berhasil dibuat lebih menarik lagi, 2) menyiapkan media yang diperlukan untuk membantu pengajaran, dan 3) menyusun lembar pengamatan pembelajaran.

Tahap pelaksanaan dilakukan dengan melaksanakan skenario pembelajaran yang telah direncanakan, sebagai berikut: 1) pemanasan; menjelaskan kegiatan belajar mengajar secara umum, melakukan pemanasan. Pemanasan dikemas dalam sebuah permainan sederhana yaitu permainan bola ranting. Siswa dibariskan berbanjar dua regu, barisan depan membawa masing-masing satu bola, kemudian bola dioperkan kebelakang. Barisan paling belakang kemudian berlari ikedepan dan mengoperkan kembali kebelakang, begitu seterusnya. 2) inti Pelajaran; memberi panjelasan materi yang akan diberikan. Siswa melakukan gerak dan teknik dasar permainan tenis meja. Siswa di bagi menjadi 2 regu, Siswa memukul bola yang dilemparkan oleh temannya dan di pantulkan kelantai kembali ke arah temannya dan kembali ke barisan dan menempati tempat yang paling belakang. siswa di bagi dua sab dengan jarak masing-masing 2 rentang lengan. Siswa melakukan latihan teknik dasar permainan tenis meja dengan memukul bola yang dipantulkan ke dinding. Siswa mencoba melakukan rangkaian gerakan teknik bermain tenis meja dengan media dinding sebagai lawan main. Setelah siswa melakukan rangkaian gerakan teknik bermain tenis meja dengan media dinding, Siswa melakukan teknikteknik tenis meja dengan modifikasi alat pembelajaran, kemudian siswa melakukan rangkaian gerakan secara keseluruhan. Siswa melakukan sesuai unit absen dan diambil hasil belajar yang sudah ditunjukkan oleh siswa sebagai bahan evaluasi pada Siklus II.

Pada kegiatab penutup; melaksanakan penenangan/pendinginan. Pendinginan dilakukan berupa pelemasan dengan cara saling memijit kaki teman. Setelah pendinginan, dilakukan evaluasi mengenai pembelajaran yang telah dilakukan. Evaluasi dilakukan dengan memberikan waktu pada anak untuk bertanya gerakan mana yang dirasa cukup sulit dan peneliti memberikan respon dengan menerangkan gerakan-gerakan yang seharusnya dilakukan dengan benar. Berdoa dan siswa dibubarkan.

Dari hasil observasi disimpulkan bahwa siswa semakin antusias melakukan pembelajaran, tampak tidak ada kejenuhan dari siswa. Siswa tidak malas belajar dan selalu ingin menambah tempo belajar. Saat pemanasan siswa terlihat senang dan gembira dengan pemanasan yang dikemas dengan cara permainan. Siswa lebih banyak bergerak dan melakukan dengan rasa antusias. Pada saat pembelajaran siswa tampak senang dengan penyajian materi. Melalui modifikasi alat pembelajaran siswa sudah mulai bisa menikmati pembelajaran dan karena model kompetisi yang digunakan, siswa terlihat saling ingin mengalahkan teman yang lainnya. Siswa juga senang dengan modifikasi alat pembelajaran yang diberikan. Hal ini terlihat dari sikap siswa yang cenderung selalu ingin mencoba lagi. Pada pembelajaran bermain tenis meja, dilakukan secara keseluruhan. Dari belajar teknik dasar sampai bermain tenis meja siswa terlihat senang dengan modifikasi alat pembelajaran yang diberikan dan cukup membuat siswa merasa tertantang untuk bermain tenis meja.

Pada pembelajaran dengan modifikasi alat pembelajaran cukup memberikan gairah dan nuansa baru pada pembelajaran bermain tenis meja, hal ini dapat dilihat dari hasil tes pada siklus II yang memuaskan.

Tabel 4.3: Diskripsi Data Akhir Siklus II Hasil Belajar bermain Tenis Meja

\begin{tabular}{|c|c|c|c|c|}
\hline Rentang Nilai & Keterangan & Kreteria & Jumlah anak & $(\%$ \\
\hline$\geq 90$ & Memuaskan & Tuntas & 1 & 3 \\
\hline $80-89$ & Baik & Tuntas & 6 & 19 \\
\hline $70-79$ & Cukup & Tuntas & 20 & 64,52 \\
\hline $61-69$ & Kurang & Tidak Tuntas & 3 & 9,68 \\
\hline$\leq 60$ & Gagal & Tidak Tuntas & 1 & 3,23 \\
\hline \multicolumn{3}{|c|}{ Jumlah } & 31 & 100 \\
\hline
\end{tabular}

Dari hasil tes pada siklus II menunjukkan bahwa hasil belajar bermain tenis meja yang dilakukan oleh siswa meningkat dari $29.03 \%$ pada kondisi awal menjadi $41,94 \%$ pada akhir siklus I dan meningkat menjadi 
87,10\% pada akhir siklus II. Perbandingan hasil belajar pada akhir siklus I dan akhir siklus II disajikan dalam bentuk diagram 1.

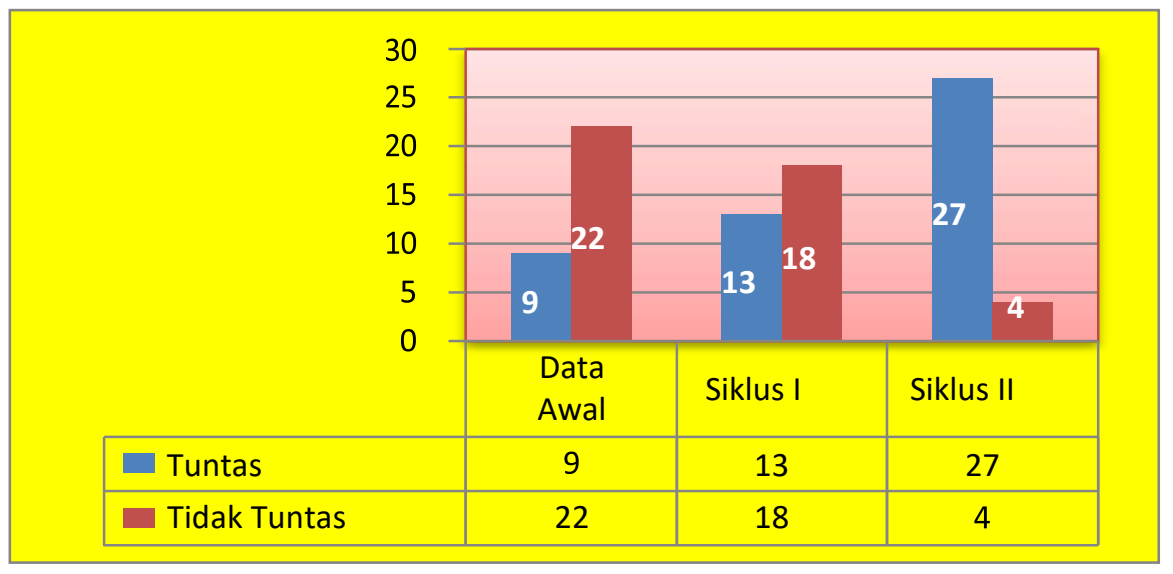

Diagram 1. Perbandingan Jumlah Siswa Data Awal, Siklus I dan Siklus II Hasil Belajar bermain Tenis Meja

Dengan hasil yang mengacu pada diagram tersebut maka dapat disimpulkan bahwa dengan penerapan modifikasi alat pembelajaran memberikan banyak manfaat dan pencerahan dalam metode pembelajaran teknik dasar dan bermain tenis meja lebih menantang siswa untuk melakukan latihan bermain tenis meja pada kegiatan belajar mengajar yang dilakukan.

\section{Pembahasan}

Hasil Penelitian Tindakan Kelas ini dari kondisi awal sampai ke siklus II mengalami peningkatan yang signifikan. Untuk melihat perbandingan kondisi tersebut dapat dirincikan kedalam diagram 2.

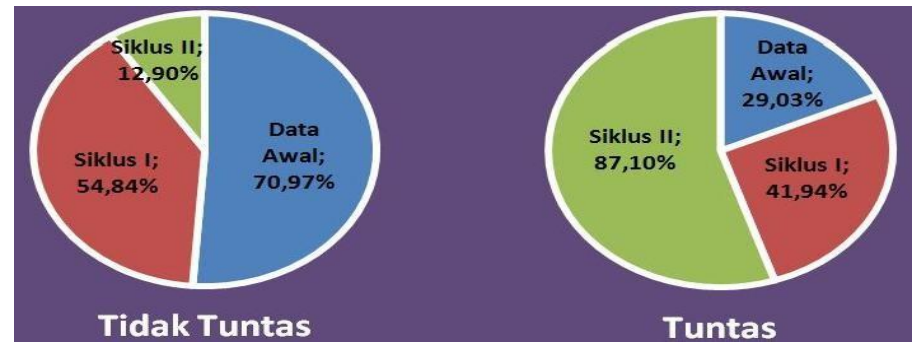

\section{Diagram 1. Perbandingan Persetase Data Awal, Siklus I dan Siklus II Ketuntasan Hasil Belajar bermain Tenis Meja}

Berdasarkan hasil penelitian, kondisi awal atau pra siklus ketuntasan hasil belajar yang memiliki ketuntasan $29,03 \%$. Sedangkan yang tidak tuntas adalah $70,97 \%$. Hasil belajar pra siklus materi bermain tenis meja yang menjadi rumusan masalah penelitian, melalui media dinding peneliti mengharapkan dapat meningkatkan hasil belajar bermain tenis meja.

Pada siklus I yang memiliki kategori tuntas $41,94 \%$ sebanyak 13 siswa, kategori tidak tuntas $54,84 \%$ sebanyak 18 siswa. Setelah adanya penerapan media memantul bola ke dinding terlihat peningkatan yang cukup baik pada siswa. Dalam pelaksanaan siklus I tidak lepas dari ketidak tuntasan hasil belajar, yang mana ketidak tuntasan tersebut menjadi rencana perbaikan pada pelaksanaan siklus II.

Rencana perbaikan yang didapat dari siklus I yang dijadikan persiapan tindakan dan menghasilkan ketuntasan yang memuaskan. Dari hasil tes pada siklus II menunjukkan bahwa hasil belajar bermain tenis meja yang dilakukan oleh siswa meningkat dari 29,03\% pada kondisi awal menjadi 41,94\% pada akhir siklus I dan meningkat menjadi $87,10 \%$ pada akhir siklus II.

\section{SIMPULAN}

Penelitian Tindakan dilaksanakan dalam dua siklus. Setiap siklus terdiri atas empat tahapan, yaitu: 1) perencanaan, 2) pelaksanaan tindakan, 3) observasi dan interpretasi, dan 4) analisis dan refleksi. Berdasarkan analisis data yang telah dilakukan dan pembahasan yang telah diungkapkan pada Bab IV, diperoleh simpulan bahwa pembelajaran melalui penerapan modifikasi alat pembelajaran dapat meningkatkan hasil belajar bermain Tenis Meja. Dari hasil analisis yang diperoleh peningkatan yang signifikan dari siklus I dan siklus II. Hasil belajar Bermain Tenis Meja pada siklus I dalam kategori tuntas adalah 45,16\% jumlah siswa yang tuntas 
adalah 14 siswa. Pada siklus II terjadi peningkatan prosentase hasil belajar siswa dalam kategori tuntas sebesar $87,10 \%$, sedangkan siswa yang tuntas 27 siswa.

\section{UCAPAN TERIMA KASIH}

Terima kasih yang sebesar-besarnya kami ucapkan kepada Kepala Sekolah SD Negeri 50/II Lubuk Landai Kecamatan Tanah Sepenggal Lintas Kabupaten Bungo. Kami juga ingin berterima kasih kepada temanteman yang banyak membantu kami dalam menyelesaikan proyek ini dalam jangka waktu yang terbatartikel ini hingga dipublikasikan.

\section{DAFTAR PUSTAKA}

Arikunto, Suharsimi. 2010. Dasar-Dasar Evaluasi Pendidikan. Jakarta: Bumi Aksara.

Arikunto, Suharsimi dkk. 2014. Penelitian Tindakan Kelas. Jakarta: Bumi Aksara.

Atmaja Prawira, Purwa. 2016. Psikologo Pendidikan dalam Prepektif Baru, Yogyakarta: Ar-Ruzz Media.

Daryanto, 2010. Belajar dan Mengajar. Bandung: CV Yrama Widya.

Dimyati dan Mudjiono. 2009. Balajar dan Pembelajaran, Jakarta : Rineka Cipta

Ekawarna, 2010, Penelitian Tindakan Kelas, Jakarta: Gaung Persada

Hamzah dan Nurdin, Mohamad, dkk. 2016. Belajar dengan Pendekatan PAIKEM, Jakarta : Bumi Aksara

Hanafiah, Nanang dan Suhana, Cucu. 2009. Konsep Startegi Pembelajaran, Bandung: PT Refika Aditama.

Hernawan, Asep Herrry, dkk. 2007. Pengembangan Kurikulum dan Pembelajaran. Jakarta : Universitas Terbuka

Jamil, Nurlah. Dkk. 2016. Pedoman Penulisan Skripsi. Bungo: STKIP Muhammadiyah Muara Bungo.

Jones dan Angela Buxton. Tanpa Tahun. Belajar Tenis untuk Pemula. Bandung: CV. Pionir Jaya

Marzuki, 2002, Metodologi Riset, Yogyakarta: Fakultas Ekonimi UII Muklis, 2007, Tenis Meja, Klaten: PT. Macanan Jaya Cemerlang

Muslich, Mansur. 2014. Melaksanakan PTK itu Mudah. Jakarta: Bumu Aksara.

Redaksi Sinar Grafika. 2008. Undang- Undang SISDIKNAS. Jakarta : Sinar Grafika

Purwanto, 2013, Evaluasi Hasil Belajar. Yogyakarta: Pustaka Pelajar

Rusman, 2013. Belajar dan pembelajaran Berbasis Komputer Mengembangkan Profesionalisme Abad 21, Bandung: Alfabeta

Setyosari, Punaji. 2012. Metode Penelitian Pendidikan dan Pengembangan. Jakarta : Pernada Media Group Syah, Muhibbin. 2012. Psikologi Belajar. Jakarta : Raja Grafindo Persada.

Syarifuddin, Aip dan Muhadi. 1992. Pendidikan Jasmani dan Kesehatan, Jakarta: DP dan K Dikti PPTK

Thobroni. M, 2016. Belajar dan Pembelajaran Teori dan Praktik, Yogyakarta: Ar-Ruzz Media

Thoha, M. Cahabib. 2003, Teknik Evaluasi Pendidikan, Jakarta: PT. Raja Garfindo Pesada. 